\title{
Affective learning for effective communication
}

Emotion and prosody in theatre improvisation

Apprentissage affectif pour une communication effective : l'émotion et la prosodie dans une démarche d'improvisation théâtrale

Christopher Mitchell, Rebecca Guy, Anda Fournel, Avril Treille and Marieke De Koning

\section{OpenEdition}

\section{Journals}

\section{Electronic version}

URL: http://journals.openedition.org/tipa/3297

DOI: $10.4000 /$ tipa.3297

ISSN: 2264-7082

Publisher

Laboratoire Parole et Langage

Electronic reference

Christopher Mitchell, Rebecca Guy, Anda Fournel, Avril Treille and Marieke De Koning, « Affective

learning for effective communication », TIPA. Travaux interdisciplinaires sur la parole et le langage

[Online], 35 | 2019, Online since 17 July 2019, connection on 25 July 2019. URL : http://

journals.openedition.org/tipa/3297; DOI : 10.4000/tipa.3297

This text was automatically generated on 25 July 2019.

\section{cc)}

La revue TIPA. Travaux interdisciplinaires sur la parole et le langage est mise à disposition selon les termes de la licence Creative Commons Attribution - Pas d'Utilisation Commerciale - Pas de Modification 4.0 International. 


\title{
Affective learning for effective communication
}

\author{
Emotion and prosody in theatre improvisation \\ Apprentissage affectif pour une communication effective : l'émotion et la \\ prosodie dans une démarche d'improvisation théâtrale
}

Christopher Mitchell, Rebecca Guy, Anda Fournel, Avril Treille and Marieke De Koning

\section{Introduction}

1 The obstacles to learning a second language are considerable. There is the challenge of getting to grips with the complexity of a new grammar system and a different syntactical structure. The apparently simple task of learning a new vocabulary is experienced as a daunting challenge when the learner is confronted with the frustration of trying to express needs, thoughts and ideas in a foreign language. The difficulties of this challenge and the fear of making mistakes can clearly have a negative impact upon learner confidence. In addition to this, the language classroom is not an environment which is conducive to language learning: encumbered with tables, chairs and computers, which occupy most of the space, it does not permit the movement which stimulates learning through the increased production of the neurochemical endorphin. A language lesson which began with learners walking in the classroom space would increase the production of these endorphins. In addition, the inclusion of music as an accompaniment could be of additional benefit, as it has also been shown that music induces feelings of pleasure through the increased production of the neurotransmitter dopamine (Mallik et al., 2017). But the learner spends most of the time seated, in an environment far removed from that in which the acquisition of the mother tongue took place. These cognitive, physical and environmental challenges impinge most upon the oral communication aspect of the language learning process. 
2 The research area linked to the work set out in this paper has a general and a specific focus. The general focus is on how classroom activities on body and voice can improve the quality of oral communication in the language learner. The specific focus which we examine here is how the relationship between emotion and prosody, or the musicality of speech, can be used to help learners to find the appropriate prosody for the target language. All of our work on oral production including prosody, whether it be of an action- research nature or in on-going teacher training, takes place around two praxes, the Silent Experience and the Engaged body, and a frame of reference known as AFEEL. The latter clearly identifies the role of emotion in our work.

Theatre, which we use in our work, is an artistic discipline which clearly provides the opportunity to bring together emotion, body and voice in a process of communicative and constructive learning. Our research is allied to the preparation of ongoing teacher training workshops and support material, to enable those involved in the language teaching and learning process to feel more comfortable in their work on oral communication. This paper lays out the theory and background to this work.

\section{Prosody and emotion}

4 Prosody, derived from the Greek word prosodia, describes the melodic and rhythmic modulations which accompany speech. It is every individual's first experience of their mother tongue, taking place before birth. Gervain and Werker (2008) suggest that learning about languages begins in the womb, with the baby able to hear the intonational contours of the language. The baby hears this language even after the filtering effect of the womb on the fine details of speech has taken place (Mehler et al., 1988; Moon et al., 1993). Babies as young as three days of age indicate a preference for the sound of their native language, the language spoken by the mother during pregnancy, over foreign languages (Kreiner \& Eviatar, 2014). This preference has been attributed to the familiarity of the prosodic patterns of their native language (Christophe et al., 2001 Mehler et al., 1988). Babies also display an ability to discriminate between two languages that they have never heard before (Mehler et al., 1988; Nazzi et al., 1998). The work by Mehler et al. indicates the link between language discrimination and suprasegmental, prosodic cues. Kreiner and Eviatar as well as Mehler et al. suggest that the prosodic sensitivity at an early stage of development may serve as a precursor to language acquisition. Locke (1993, p. 8), who describes prosody as the child's bridge to grammar and syntax, explains the motivation of children to pay attention to speech as the result of $a$ deep biological need to interact emotionally with the people that love and take care of them.

There are two types of prosody that have been identified: linguistic prosody, which describes the stress, rhythm and intonation features of speech, and affective prosody which is a description of the emotional aspect of speech (Belyk \& Brown, 2013) or, in other terms, the expression of subjectivity. According to Caelen-Haumont and Bel (2003) the affective dimension of prosody depends on a person's ability to invest himself subjectively in his words, which may, of course, vary according to the situation (p. 187). ${ }^{1}$ Although their communicational functions are different, the two types of prosody use the same common set of acoustic cues related to pitch, volume, rhythm and timbre (Belyk \& Brown, 2013). 
The importance of prosody in effective communication has been picked up and quite extensively investigated in the last three decades. Lengeris (2012), amongst others, cites numerous studies in which prosody has been found to be linked to accentedness, comprehensibility and intelligibility of speech (p. 25). Concerning intelligibility, prosody has been identified as one of the most important factors, transcending work on segmental aspects in terms of bringing about improvement (see for example Derwing \& Rossiter, 2003). Aronsson (2014) highlights the importance of both prosody and emotion:

Suprasegmentals play an important role in communication, not only for reasons of intelligibility, but also for the conveyance of essential pragmatic and emotional aspects that facilitate the smooth flow of a spoken dialogue (p. 7).

7 As research indicates (Prieto \& Esteve-Gibert, 2018 ; Speer \& Ito, 2009) prosody is an important foundation stone of language acquisition, and crucial to intelligibility in oral communication contexts. The teaching of it presents one of the biggest challenges in second language pedagogy, as shall be discussed below. It is a challenge that is not always taken up: thus the place of prosody in language teaching is often neglected. The fact that it is absent from so much foreign language teaching makes the task of the language learner more difficult when it comes to oral production. Our aim here is to show how the relationship between emotion and prosody can be exploited to aid the learner's quest for appropriate prosody.

\section{Prosody in language teaching}

The learning of a second language is a very different experience from that of acquiring the first language or mother tongue. The focus on the segmental aspects of speech, as well as grammar, syntax and the accumulation of vocabulary from an early stage of second language learning differentiates the classroom experience from the exploratory (including physical environment and sound), tactile and emotional experience of first language acquisition. These differences mean that prosody is all too often neglected in formal language learning contexts.

It has been noted that the importance of prosody as a focus of research is not reflected in classroom practice. Aronsson (2014) pointed out that since Van Els and De Bot's (1987) suggestion that more work remained to be done on the learnability and teachability of the intonation of a foreign language, the gulf between what was happening in research and what was happening in the classroom had not yet been bridged. This gap between research and teaching has been highlighted elsewhere. Gut et al. (2007) note in their paper on the case of prosody in non-native speech that [R]esearchers do rarely go to language classes and teachers do rarely go to scientific conferences (p. 5), observing that both groups expressed dissatisfaction with what the other group was providing. Although they claim that $[T]$ he aim of language teachers is to enable language learners to produce and perceive the prosody of the target language to an adequate extent, depending on the learner's needs (p.4), there is little evidence to show that such an aim is being translated into practice in the classroom. One reason for this may be, as pointed out by Lengeris (2012), that findings which are contained in research papers may be presented in such a way that renders their inclusion in the teaching curriculum difficult. Another reason that Lengeris puts forward concerns non-native teachers: in the debate around this group of teachers the question of the teaching of prosody by such teachers, and their sensitivity to the quality of their own prosody, is rarely touched upon. The lack of a system of notation for prosody 
does not help their case. This fact may lead to the belief that prosody cannot be taught, a belief that may also be found in native teachers, and this notion of 'unteachability' may in itself encourage the mistaken idea that ultimately prosody is not that important.

\section{The Silent Experience and the Engaged Body}

Silent Experience - The sentient quality of the Silent Experience praxis clearly distinguishes its inclusion in language work in the classroom from a typical cognitive learning experience. The learner is encouraged to subjectify the language learning experience by placing their own body at the source of what is happening, preparing the learner to recognise the importance of the body and the voice in the oral production of language. Silent Experience exercises are designed to allow the learner to feel, and to listen to, the sensations within the body. Initially, the silence is an active silence in which the central role of the diaphragm in breathing is explored, during time spent simply breathing naturally, with the eyes closed. Following on from this, consciousness of the air passing between the lips on the outgoing breath reveals breathing as the carrier of sound. That which may appear as a simple and obvious observation is in fact the first step in allowing the mind and the body to become (re)connected in oral production. Prior to, and throughout the breathing exercises, the importance of body posture has a central focus. Changes in posture are shown to affect breathing. The Silent Experience is pursued with exercises on articulation (jaw, lips, tongue, soft palate), aimed at allowing the learner to become more aware of what is happening in the shaping of sound.

11 Words and text are then added. As with breathing exercises, sound is initially absent in the act of reading aloud. That is to say, silent or voiceless reading aloud precedes voiced reading aloud. Although language teachers may find the idea of encouraging so much deliberate silence in the language classroom runs counter to good pedagogical practice in language teaching, neuroscience has identified the act of silent reading as a link to phonology and emotion within language (Perronne-Bertoletti et al., 2016). Speech confined to the interior, without sound, can show variations in rhythm and pitch (Mackay, 1992). More recently, neuroimaging with FMRI scans has confirmed the presence of the inner voice during silent reading which can include variations in intonation and rhythm (Loevenbruck et al., 2005).

The video that accompanies this paper, to be discussed below, illustrates an approach which uses aspects of the Silent Experience praxis when adding an emotional context to a simple sentence, in the pursuit of improving prosody.

The Engaged Body - In his work on proxemics, Hall (1966) defined the different spaces in which humans interact, moving from intimate space through personal and social space to public space, and how the individual perceives and uses each space. Much of his work and later work by researchers (Loewen, 1969; Ickinger, 1982; Watson 1972) has focused on the physical behaviour of the individual within each space, including touching, proximity and non-verbal communication, taking into account cultural variations. Our second praxis, the Engaged Body, is concerned with how space is perceived in what we like to call the speaking arena, which can range from intimate conversation to public speaking. This praxis includes activities which have the aim of showing how the body subjectivises the experience of spatial relationship, with the listener(s) and with the physical surroundings and how this subjective experience is significant in terms of vocal quality when the voice 
is projected into this space. The projection or placing of the voice within the speaking arena is affected by this perceived relationship with the other and the space. The interaction that takes place may range from the minimum, in what Rodenburg (2009) describes as the First Circle of speaking, where the speaker is perceived to be holding a conversation with him or herself (a university lecturer mumbling the contents of his paper in front of an amphitheatre of students is an example of this), to a communication described as Third Circle speaking which goes beyond those physically present (as in the case of a politician using a stentorian delivery to an audience as if to the whole world, talking at, or over, people present rather than talking to them). In both cases the listener will feel excluded from the communication. Rodenburg describes Second Circle delivery as one which has real engagement with the listener. We have chosen to describe these three circles in terms which we believe are more accessible to the learner: the First Circle voice is one that exists in the Interior Zone, the Third Circle voice is in the Exterior Zone and the voice that really communicates, the Second Circle voice, is in the Engagement Zone. Here, the speaker is present, connected to the immediate environment, taking into account the listener and herself. The aim is to help language learners to accrue confidence in their oral communication through an understanding of how the body, the source of speech, relates to the speaking environment and the presence of the listener within it, and how it can positively impact the quality of this relationship.

\section{The AFEEL frame of reference}

Our approach to prosody takes the learner towards an increased awareness of self and the other through the experience of focusing on what is taking place in the body, before and during speech, while incorporating the contextual environment of speech. In our ongoing teacher training workshops, this approach is structured around a frame of reference designated by the acronym AFEEL, which alludes to those fortunate individuals who have "a feel for languages" - that is to say, who have good skills in languages and little trouble learning a new language. We developed AFEEL to provide a checklist for teachers, as a set of ideas that can guide teachers in their work on body and voice.

AFEEL is:

16 Awareness - Being aware of one's own body, of the environment, the space in which one is situated, and being aware of the other(s) is the basis of all work on body and voice.

17 Focus - This is a concomitant of awareness. The speaker must be conscious of whom he or she is looking at when speaking. Being aware of the space between speaker and listener will help the speaker to manage vocal sound more effectively.

Energy - Corporal energy has an important effect on the dynamic quality of communication: that is to say, on how the speaker feels and is perceived, visually and vocally.

Emotion - When emotion is evoked, the speaker is seen, or more precisely heard, to identify with the content of their words. Our working hypothesis in the formulation of pedagogical activities of the type discussed in this paper is that when emotion is involved, greater prosodic variation follows.

Liberation - All work on Awareness, Focus, Energy and Emotion is done with the aim of achieving greater corporal and vocal freedom in oral production. This liberation should 
leave the speaker more confident, able to produce a more appropriate prosody and apply it as a tool for efficient communication.

\section{Emotions and Feelings}

As evidenced by the name of the AFEEL frame of reference and its inclusion of emotion, the importance of defining clearly what is meant by 'emotion' and 'feeling' has been recognised. Physical awareness is an essential prerequisite to any work on the emotional and sensory aspects of language, leading the learner towards what Damasio (2000) describes as the feeling of what happens.

In Silent Experience work the first focus of feeling is a physical one: the individual's attention is drawn to their contact with the floor. This establishment of an awareness of physical feeling is important for achieving balanced posture and good breathing. The relationship between posture and emotion has been the subject of a considerable amount of research work, some of which is cited by Winters (2005) when she asks the question To what extent do people agree on which emotions are associated with specific body postures? The subject of all of the work referenced by Winter is the perception of emotions based on body posture as viewed from the exterior. Our perspective is more focused on the association of emotion with how posture is experienced by the speaker, how it is felt from the interior. The learner is encouraged to orientate her attention towards how assuming different postural positions allows her to experience the effect on emotion of these different positions. In this period of silence, associated with assuming different posture positions, the learner is able to orientate her attention to what is happening physically within the body. Linklater (2006, p.328), in acknowledging the influence of the work of Damasio on her own work as a voice coach, observes that her approach to voice aims to restore direct neurophysiological pathways for the voice to travel through the body, arousing physical, sensory, sensual and emotional response. We call this resultant voice a whole body voice. Whereas Linklater speaks of 'arousing' an emotional response, we prefer to consider our voice work as being aimed at increasing the opportunities for the learner to be encouraged towards prosodic variation within the voice, through an increased sensitivity to all that is happening, physically and mentally, within the body prior to and during speaking.

Much of this work, which will be described in detail below, takes place in conditions which involve emotional context and theatre style activities including work on improvisation. This enables workshop participants to reflect on Damasio's description of emotions playing out in the theatre of the body and feelings playing out in the theatre of the mind (Damasio, 2003, p. 7).

\section{Emotion in context}

The issue of how to integrate effectively oral work into the language classroom is the subject of much debate. A regular diet of gap-fill exercises, learning of vocabulary lists, multiple-choice tests, classroom presentations and limited talking time has shown itself to be inefficient, and insufficient, in improving oral production. Stevick (1980) gives some guidance in saying that it depends less on materials, techniques, and linguistic analysis, and 
more on what goes on inside and between the people in the classroom. Arnold (2011) cites Stevick, acknowledging that many others have also done so, when stating that the:

inside and between is basically what affect is about: on the one hand, the individual or personality factors (...) which we can consider as inside the learner, and on the other, the relational aspects which develop between the participants in the classroom - between students or between teacher and students - or possibly between learners and the target language and culture.

What is missing from the list of factors cited are those experiences which have already been described in the two praxes above, namely the physical relationship between the speaker, listener, and the physical environment. It is these, as well as the factors cited by Arnold, which mean that learning can take place in a context of emotion, as opposed to the emotion vacuum of so many classroom exercises, even those dedicated to oral production, such as listen-and-repeat drills and role plays. In the theatre work we are developing it is an emotional context in which things happen, in exchanges of a dramatic nature between characters, situating this work closer to the process of language acquisition than second language learning; as Krashen (1983) observed, when talking of the development of the mother tongue, acquisition is where the action is.

However, before we use the term 'emotional context' with regards to our theatre work we have to address the question 'what is an emotional context'? Caldwell-Harris (2014) makes a theoretical proposal that using a language in emotional contexts provides it with emotional resonances because human experiences are learned and stored in a context-dependent manner. She argues that a language which is learned as a child will carry strong emotional resonances. The family context of learning means that everyday language carries the full range of human emotions. But the emotional resonances of childhood, in terms of language, may vary greatly from child to child depending on social background, family relationships, life experience and education. Caldwell-Harris equates frequent usage with emotional usage, but this link is questionable. For instance, an example of frequent usage would be the cliché. However, it is the very nature of a cliché to be used frequently, and it is this which strips it of emotional resonance. In writing of clichés Hargraves (2014, p. 11) observed that [A]ll speakers find them extremely useful to smooth the steady flow of speech but then went on to add [C]lichés are the sterile offspring of a mind that is not engaged in creativity (p. 14). Although she does not refer to that prosaic usage which is the subject of Hargraves' work, Linklater (2000) speaks of the utilitarian nature of language today, observing that in their passage directly from the speech cortex in the brain to the mouth, words very rarely pick up an emotional charge. There is, according to Linklater, a need to restore words to the body, prioritising their sensory nature, and a need to redress the balance between intellect and emotion. We seek this redressment, with the aim of improving prosody, via a consideration of the structure of language and its interaction with the body in our specific theatre texts and improvisation work.

The video accompanying this paper demonstrates a short exercise fusing Silent Experience work with the provision of an emotional context to investigate the effect of emotion on learner prosody. This video exercise differs from our typical teacher training workshops, in which such an exercise would be preceded by body and voice activities, as the students in this recording had no preparation, other than simply the time to read the text (two phrases - I don't want to do it anymore. I'm going to leave) in order to be able to say it without reading. 

the participants. We focused our observations on the voiceless speaking aloud stage (Stage 3) and observed the gestural, facial and corporal behaviour produced by the speakers, linked to the context described. We then observed if there were changes between the first and fourth stages in terms of prosody. are:

- Between stage 1 and stage 4: more physical expression linked to what is being said, in addition to more variations in pitch and duration of some of the syllables in stage 4 . These can both be considered as indications of an improved prosody during the experiment. 


\begin{tabular}{|l|l|}
\hline $\begin{array}{l}\text { Video } 4 \text { - all participants } \\
\text { https://youtu.be/wJ-QwmFCuRk }\end{array}$ & - comparison S1 and S4 \\
| https://youtu.be/wJ-QwmFCuRk \\
\hline
\end{tabular}

- Between stage 3 and stage 4: even if the body is clearly more engaged in stage 4 than in stage 1 , stage 4 shows less facial mimics and physical (external) movements or gestures than stage 3. Obviously, the students had been asked to "avoid overplaying with theatrical gestures", but it seems as if the visible, physical movements - inspired by the emotional context - had been replaced by vocal movement, that is to say prosody.

\begin{tabular}{|l|l|}
\hline $\begin{array}{l}\text { Video 5 - all participants } \\
\text { https://youtu.be/fBo9CLGn4fA }\end{array}$ & - comparison S3 and S4 \\
| https://youtu.be/fBo9CLGn4fA \\
\hline
\end{tabular}

At the present time the precise modalities for assessing scientifically the change in prosody between the two vocalised deliveries have not been established. However, in all cases a perceptible change in prosody has been observed: the voiced version following the work with enacted emotion (via the supplied imagined emotional context) shows an audibly greater range in intonational variation.

\section{Theatre in language teaching - a specific approach}

The word 'theatre' means different things to different people. It can be the building in which a theatrical performance takes place, the stage on which the actors perform, the actors themselves, or writing organised in such a way to present itself as a theatre text. The word 'drama' can further confuse the discussion and much argument takes place, particularly in artistic circles, on the difference between the two.

These different perspectives on, and definitions of, theatre and drama, are reflected in the language classroom. Working with theatre texts, drama games, improvisation and role plays are all activities which are grouped under the words "theatre" and "drama", and both the content and goal of all such activities may be interpreted differently according to the teacher or artistic performer working with learners. Gandara Rauen (1990) poses many of the questions and answers around the arguments for using drama in the language classroom and Paul (2015) contrasts the communicative approach to language learning with the use of improvisational theatre techniques. There is much emphasis here on the importance of collaboration, the role of the group, and the creation of an atmosphere in which mistakes can be made.

Our approach is very specifically orientated, mixing the doing of drama and the viewing of theatre (to adapt the description from Gandara Rauen, 1990, p. 273), particularly with its use of improvisation work. There is less emphasis on the group experience, although this is important in improvisation, and more on the corporal and vocal experience of the individual. The body and voice exercises and activities found in our theatre workshop are very similar to those used in professional acting training. In addition, many of the group energy exercises are games, or variants, of exercises found in many team-building and drama workshops. 
specific approach comes to the fore in text work and improvisation exercises, in which the focus is very much on the role of emotion. In all this work there is emphasis on the learner's role also as observer and critic. Encouraging learners to be more sensitive to what is happening with other learners will help them to have an improved insight into what is happening in their own body and voice.

\section{Co-construction of emotions}

Our theatre work is always structured around the presence of at least two learners. Given the process which is taking place in this work the word 'learner' appears inadequate to us if we want to put the emphasis on the process of acquisition. In improvisation competitions in France the participants are known as jouteurs reflecting the notion of jousting which takes place in improvisations. However, this jousting is not a combat, but a form of construction in which the participants try to create a scene together. The description of participants in improvisation work in a language class as coaction learners or coactors seems to reflect more appropriately the nature of the work found, as in psychological terminology in which cofactors are people who work together on a joint action (Knoblichet al., 2008, p.61). These coactors take part in a process of co-construction of emotions. Pepin (2008, p.4) describes emotions as being, in the process of social interactions, jointly constructed, deconstructed and reconstructed by the participants.

\section{Texts}

We have recently created original short theatre texts to provide learners (including teachers) with examples of the style of text which can help in the exploration of prosody. (An example of one such text, TT1 - A Walk, is given in the appendix). The texts have been, and are being, created by a member of the group who as a theatre director has a long experience in the creation of theatre texts with language learners and actors.

Work with language learners has revealed the importance of allowing the speaker to easily identify prosodic boundaries. In the layout of these texts there is an importance attached to bringing out the prosodic nature of writing. Arronson (2014) notes that the oral tradition of communication meant that it was only in medieval times that information which expressed meaning on a prosodic level started to appear in print. Punctuation, spacing, font size, the use of boldface and italics are all ways of guiding the reader towards stress, rhythm and punctuation in order to experience the prosodic nature of writing.

The minimalist language used in the texts reduces the cognitive load for a language learner, avoids blocking the form of the speech with content, and provides the opportunity to play with the sounds of words. Stage directions including body positions are given, which suggest emotions without detailing them, giving the cofactor the opportunity to explore how emotions can be linked to body position and context, and see how different emotions can affect the interpretation of the text. In association with these texts, extracts from texts by Harold Pinter can be read and staged to show how minimalist text and silences (the famous Pinter pauses) can create an atmosphere of menace. $^{2}$

TIPA. Travaux interdisciplinaires sur la parole et le langage, 35 | 2019 
The texts are to be used in the following way in order to explore our approach to its full advantage:

a. The class reads the text silently in order to verify that everyone understands all the words and their pronunciation. This should not pose any serious problems as the texts use simple vocabulary and constructions.

b. The class reads the text together aloud, with each coactor reading one cue or stage direction at a time. Pronunciation is corrected if/as necessary.

c. The class reads the text silently aloud following the guidance given to this exercise in Silent Experience activities.

d. Two coactors read the roles in the text aloud, to the class. Depending on the length of the text the coactors can be changed during the reading.

e. The text is staged. If the classroom space permits the group works in pairs, in different areas to do this. Otherwise two coactors stage the text in front of the group. All observers play the role of stage director, noting what they observe, vocally and corporally, during the staging.

f. The group, coactors and observers, discuss together what they felt and observed, during the staging.

Caldwell-Harris (2013), in a study of expressing emotions in different cultures, cites the Confucian saying do more, say less. A more appropriate description of our approach in improvisation and text work might be feel more, say less.

\section{Conclusion}

The specific approach based on body and voice, described and analysed in this paper does not constitute a complete pedagogical method. Teachers are encouraged to identify moments in a traditional language learning course when body and voice activities can be inserted. Nevertheless, the desire in all language learning must include the wish to improve the quality of oral communication, and Linklater has described perfect communication as a balanced quartet of emotion, intellect, body and voice (2006, p. 9). Even if perfect communication is not possible, the quartet that Linklater cites should serve as a guide to the language teacher in creating a language course that encompasses all aspects of oral communication. The way we use improvisation, the specific combination of simple text and physicality, is meant to allow more space for feeling. This will provide the opportunity to work on the balance of Linklater's communication quartet, within second language learning, in a way that is creative, motivating and liberating for both students and teachers alike.

\section{BIBLIOGRAPHY}

Adams-Goertel, R. (2013) Prosodic elements to improve pronunciation in English language learners: A short report, Applied Research on English Language, 2, 2 p. 117-128. DOI: 10.22108/ are.2013.15474 
Arnold, J. (2011) Attention to Affect in Language Learning, Anglistik: International Journal of English Studies, 22, 1, p. 11-22.

Aronsson, B. (2014) Prosody in the Foreign Language Classroom - Always Present, Rarely Practised? Journal of Linguistics and Language Teaching, Vol. 5, (2), 207-224. https:// www.researchgate.net/publication/271729402_

Belyk, M. \& S. Brown (2013) Perception of affective and linguistic prosody: an ALE meta-analysis of neuroimaging studies, Social Cognitive and Affective Neuroscience, 9, 9, p. 1395-1403. DOI:10.1093/ scan/nst124

Caelen-Haumont, G. \& B. Bel (2003) Subjectivité et émotion dans la prosodie de parole et du chant : espace, coordonnées et paramètres, in Colletta, J-M. \& A. Tcherkassof (eds) Les émotions : cognition, langage et développement, Sprimont (Belgium): Mardaga, p. 187-196.

Caldwell-Harris, C.L. (2014) Emotionality differences between a native and foreign language: theoretical implications, Frontiers in Psychology, 5.

DOI: 10.3389/fpsyg.2014.01055

Caldwell-Harris, C.L., Kronrod, A. \& J. Yang (2013) Do more, say less: Saying "I love you" in Chinese and American cultures, Intercultural Pragmatics, 10, p. 41-69.

Christophe, A., Mehler, J. \& N. Sebastian-Galles (2001) Perception of Prosodic Boundary Correlates by Newborn Infants, Infancy, 2, 3, p. 385-394. https://www.researchgate.net/ publication/

252112045_Perception_of_Prosodic_Boundary_Correlates_by_Newborn_Infants

Colineau, J. (2012) Pratique théâtrale et valorisation des émotions : des leviers pédagogiques pour l'apprentissage de l'intonation en classe d'anglais, Mémoire de Masters 2, Université d'Angers, 39 p.

Damasio, A. R. (2000) The Feeling of what Happens: Body and Emotion in the Making of Consciousness, Orlando: Harvest Books, 400 p.

Damasio, A. R. (2003) Looking for Spinoza: Joy, Sorrow and the Feeling Brain, London: Vintage, 368 p.

Derwing, T.M. \& M.J. Rossiter (2003) The Effects of Pronunciation Instruction on the Accuracy, Fluency, and Complexity of L2 Accented Speech, Applied Language Learning, 13, 1, 1-17, https:// www.researchgate.net/ publication/234570703_The_Effects_of_Pronunciation_Instruction_on_the_Accuracy_Fluency_and_Complexity_of_L2_Accented_Speec Elam, K. (1980) The Semiotics of Theatre and Drama, London: Methuen.

Gandara Rauen, M. (1990) Drama in the Language Classroom, Revista Letras, 39, p. 271-287. DOI: http://dx.doi.org/10.5380/rel.v39i0

Gervain, J. \& J.F. Werker (2008) How Infant Speech Perception Contributes to Language Acquisition, Language and Linguistics Compass, 2, 6, p. 1149-1170. DOI: 10.1111/ j.1749-818x.2008.00089.x

Gut, U., Trouvain, J. \& W.J. Barry (2008) Bridging research on phonetic descriptions with knowledge from teaching practice - The case of prosody in non-native speech, in Trouvain, J., \& U. Gut, (eds) Non-Native Prosody: Phonetic Description and Teaching Practice, Berlin: Walter de Gruyter, p. 3-25.

Hargraves, O. (2014) It's Been Said Before: A Guide to the Use and Abuse of Clichés, New York: Oxford University Press, 248 p.

Ickinger W.J. (1982) A Behavioral Game Methodology for the Study of Proxemic Behavior https:// www.sharktown.com/proxemics/gfx/media/RESEAR1.pdf 
Innovalangues (2012) Innovalangues Presentation in English. http://innovalangues.fr/ innovalangues-persentation-in-english/

Knoblich, G., Butterfill S. \& N. Sebienz (2008) Psychological Research on Joint Action: theory and data, Psychology of Learning and Motivation, 49, p. 59-101.

Krashen, S. (1983) A Child's Guide to Learning Languages, BBC Horizon TV documentary, 15'16"-15'18".

Kreiner, H. \& Z. Eviatar (2014) The missing link in the embodiment of syntax: prosody, Brain and Language, 137, p. 91-102.

DOI: $10.1016 / \mathrm{j} \cdot$ bandl.2014.08.004.

Linklater, K. (2006) Freeing the Natural Voice, London: Nick Hern Books, $392 \mathrm{p}$.

Locke, J. L. (1993) The Child's Path to Spoken Language, Harvard: Harvard University Press, 536 p.

Loewen, R.S. (1969) An experimental study of the effects of personal proximity upon selected aspects of conversational content, Masters thesis, Portland State University, 68 p.

Lœvenbruck, H., Baciu, M., Segebarth, C. \& C. Abry (2005) The left inferior frontal gyrus under focus: an fMRI study of the production of deixis via syntactic extraction and prosodic focus, Journal of Neurolinguistics, 18, 3, p. 237-258. DOI: 10.1016/j.jneuroling.2004.12.002

Mallik, A.,. Chanda, M.L \& D.J. Levitin (2017) Anhedonia to music and mu-opioids: Evidence from the administration of naltrexone, Scientific Reports, 7, 41952. DOI: 10.1038/srep41952

Mehler, J., Jusczyk, P., Lambertz, G., Halsted, N., Bertoncini, J. \& C. Amiel-Tison (1988) A precursor of language acquisition in young infants, Cognition, 29, 2, p. 143-178. DOI: 10.1016/0010-0277 (88)90035-2

Mitchell, C., de Koning, M. \& R. Guy (2018) The "Silent Experience": A New Approach to Prosody, Recherche et pratiques pédagogiques en langues de spécialité - Cahiers de l'Apliut, 37, 2. DOI: 10.4000/ apliut.6367

Moon, C., Cooper, R.P. \& W.P. Fifer (1993) Two-day-olds prefer their native language, Infant Behavior and Development, 16, 4, p. 495-500.

DOI: $10.1016 / 0163-6383(93) 80007-U$

Paul, A. (2016) Incorporating theatre techniques in the language classroom, Scenario, 9, 2, http:// research.ucc.ie/scenario/2015/02/Paul/08/en

Pelachaud, C. (2012) Emotion-Oriented Systems, ISTE: London / Hoboken, NJ: John Wiley, 352 p.

Pepin, N. (2008) Studies on emotions in social interactions, Bulletin Suisse de Linguistique Appliquée (VALS-ASLA), 88, p. 1-18.

Prieto, P. \& N. Esteve-Gibert (eds) (2018) The Development of Prosody in First Language Acquisition, Amsterdam: John Benjamins, $368 \mathrm{p}$.

Rodenburg, P. (2009) Power presentation: formal speech in an informal world, London: Penguin, 256 p.

Speer, S. \& K. Ito. (2009) Prosody in First Language Acquisition - Acquiring Intonation as a Tool to Organize Information in Conversation, Language and Linguistics Compass, 3, p. 90-110.

DOI: $10.1111 / \mathrm{j} .1749-818 \mathrm{X} .2008 .00103 . \mathrm{x}$

Stevick, E.W. (1980) Teaching Languages: A Way and Ways, Rowley, MA: Newbury House, 215 p. 
Van Els, T. \& K. de Bot (1987) The Role of Intonation in Foreign Accent, The Modern Language Journal, 71, 2, p. 147-155.

DOI: $10.1111 / \mathrm{j} .1540-4781.1987 . t b 01597 . \mathrm{x}$

Watson, O. M. (1972) Conflicts and Directions in Proxemic Research, Journal of Communication, 22, 4, p. 443-459.

DOI: $10.1111 / \mathrm{j} .1460-2466.1972 . t b 00167 . \mathrm{x}$

Winters A. (2005) Perceptions of Body Posture and Emotion: A Question of Methodology, The New School Psychology Bulletin, 3, 2, p.35-45.

\section{APPENDIXES}

\section{TT 1 - A Walk}

Legend

Word or syllable in bold - to be stressed

Word or syllable underligned - to be lengthened

$\emptyset \varnothing \varnothing$ - a pause

$\varnothing \varnothing \varnothing \varnothing \varnothing \varnothing-$ a long pause

Staging

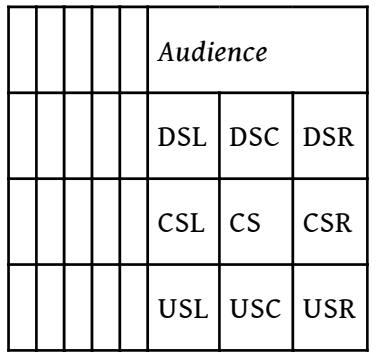

\begin{tabular}{|l|l|l|}
\hline DSL - downstage left & DSC - downstage centre & DSR - downstage right \\
CSL - centre stage left & CS-centre stage & CSR-centre stage right \\
CSL - centre stage left & USC - upstage centre & USR - upstage right \\
\hline
\end{tabular}

Three characters - A, B, C. Three chairs in a row, next to each other CS $A$ is sitting $S R, B$ is standing in front of her chair CS, C is sitting SL.

Silence

A (gets up): I'm getting up.

B (sits down): I'm sitting down.

C (looks for a long time at A and B, speaks slowly): I'm ØØØ doing nothing. $\varnothing \varnothing \varnothing$

A looks at B and C 
A (moves away SR): I'm going.

C (turns body to face in the direction of A): Hey! Stop.

A stops $\varnothing \varnothing \varnothing$ Turns slowly to look at C

A (slowly): $\underline{\text { Yes? }}$

C: Where are you going?

A (thinks): Mm - I don't know.

C, confused, looks at B

C: $\underline{\text { Er }}$-She doesn't know.

B (as if she doesn't care): She never knows.

A (with confidence): I do.

A looks at B, B looks at C, B looks at A

B: So?

A: So what?

B: Where - are - you - going?

$\varnothing \varnothing \varnothing \varnothing \varnothing \varnothing$

A: I'm going for a ØØØ walk.

B looks at C

B: She's going for a walk.

C (to A): Where?

A turns, walks back very slowly behind B's chair

A (loud whisper in B's right ear): Behind you.

A continues around and in front of $\mathrm{C}$, facing her, back to the audience

A (to C): And in front of you.

A continues her walk and sits down in her chair.

A (looking happy): I enjoyed that.

C (surprised): Do you call that going for a walk?

$\mathrm{B}($ to $\mathrm{C})$ : That is a good question. Yes. A very good question. ØØØ (to A) Well, do you?

A: I do.

$\mathrm{B}$ (to $C)$ : She does.

C (to B): I heard.

A: Isn't life fun?

B: Fun?! Fun?!

A: Yes, fun.

C: Do you think that sitting here is fun? 
A: No, sitting here - and then going for a walk - is fun.

B: Really?

A: Yes.

B looks at C

B: Let's try it!

A: $\underline{\text { Yes }} \varnothing \varnothing \varnothing$ Yes! Let's go.

NB : It is normal THEMPPO practice to refer to an unnamed character as 'she'. However referring to the character as 'he' helps to focus attention on the dropped and aspirated / h/ aitch.

\section{ENDNOTES}

1. ...de la capacité de la personne à s'extravertir, c'est-à-dire à s'investir subjectivement dans ses propos qui peuvent, bien entendu, varier selon la situation. Caelen-Haumont \& Bel, 2003, p.187 (author translation).

2. The Dumb Waiter (1957) is a good example of such a text.

\section{ABSTRACTS}

This paper presents an ongoing pedagogical project concerning the role of body and voice work in second language learning, in particular with regards to prosody and its importance for effective communication. We examine the relationship between emotion, prosody and the corporal and vocal aspects of speech, all of which have proved to be problematic areas for language teachers in the standard classroom. We have developed an approach into body and voice in the language classroom that is structured around two praxes, the Silent Experience and the Engaged Body, and a frame of reference known as AFEEL, the latter to be used as a classroom checklist for teachers. The two praxes and the frame of reference put centre stage the importance of self and spatial awareness in the corporality of oral production. In our research group's ongoing teacher training workshops and other communications, body and voice work find a natural home in theatre activities, which use enacted emotion in improvisation and text work to explore oral communication in the pursuit of more appropriate prosody in the target language.

Dans l'apprentissage d'une langue seconde, les obstacles rencontrés par les apprenants peuvent être considérables. S'attaquer à la complexité d'un nouveau système grammatical et d'une structure syntaxique différente n'est pas chose aisée. La tâche apparemment simple d'apprendre un nouveau vocabulaire peut se transformer en défi de taille lorsque l'apprenant se trouve confronté à la frustration de ne pas parvenir à exprimer ses besoins, ses désirs, ses idées et ses pensées à un niveau de compétences langagières équivalent à sa langue première. Cela peut engendrer une perte de confiance liée à la peur de faire des erreurs.

En outre, dans la classe de langue l'apprenant est souvent assis et se voit très rarement, voire jamais, proposé une mise en mouvement corporelle ou des expérimentations sensorielles. Cette situation est liée à la spécificité de la salle de classe souvent remplie de chaises, tables ou ordinateurs qui n'incite pas à l'exploration pourtant si propice à l'apprentissage. Pourtant, nous savons que le mouvement est un des vecteurs qui stimulent le développement cognitif. Ces

TIPA. Travaux interdisciplinaires sur la parole et le langage, 35 | 2019 
limites physiques liées au contexte d'apprentissage viennent impacter en premier lieu la production orale dans l'enseignement des langues Pour aller plus loin, lorsque l'espace est disponible, l'utilisation du théâtre en classe de langue permettra de déployer au maximum le corps et la voix, éléments essentiels de la communication.

Notre groupe de recherche-action s'intéresse, dans ses travaux, à la place du corps et de la voix dans l'apprentissage des langues. Un de ses objectifs est de proposer des pistes concrètes qui permettent d'améliorer la qualité de la prosodie en communication orale. Pour ce faire, elle utilise les compétences de son équipe d'enseignants, scientifiques et artistes, pour proposer aux enseignants des ateliers de formation continue et du matériel de soutien. Elle compte les amener ainsi à acquérir plus d'aisance dans leur travail sur la communication orale.

Nous avons identifié l'émotion comme étant l'axe central de recherche à explorer en lien avec la musicalité de la parole. L'émotion joue un rôle important dans la libération du corps et de la voix, et dans l'amélioration de la conscience prosodique. Le défi auquel l'équipe est confrontée est de comprendre comment la relation entre émotion et prosodie, déjà identifiée dans d'autres recherches, peut être utilisée pour aider les apprenants à trouver la prosodie appropriée dans la langue cible. Le théâtre représente, dans ce sens, l'activité qui offre clairement l'occasion de réunir l'émotion, le corps et la voix dans un processus d'apprentissage communicatif et constructif.

Le présent article expose la théorie et le contexte de ce travail. Les réflexions et illustrations qui sont proposées s'articulent autour de la question suivante : comment la relation entre l'émotion et la prosodie peut être exploitée afin d'aider les apprenants à trouver une prosodie appropriée ? L'article s'intéresse d'abord au lien entre la prosodie et l'émotion, tel qu'il a été théorisé dans le contexte de l'acquisition et du développement du langage en langue première, pour interroger par la suite sa place dans l'apprentissage d'une langue seconde. Si le rôle de la prosodie a bien été identifié dans le processus d'acquisition des premiers sons chez le nouveau-né, dans sa dimension affective, pragmatique et communicationnelle, celle-ci ne jouit pas de la même reconnaissance dans l'apprentissage d'une langue seconde. Des recherches soulignent pourtant l'importance de la prosodie, et des phénomènes suprasegmentaux associés, non seulement pour l'intelligibilité du discours mais aussi pour la transmission des aspects émotionnels dans le dialogue (Aronsson, 2014) ; la prosodie est aussi un vecteur de motivation dans l'interaction grâce à sa dimension affective et émotionnelle (Locke, 1993) ; enfin elle doit et peut être envisagée comme un pont vers l'acquisition de la grammaire et de la syntaxe.

Que la prosodie soit encore négligée en classe de langue pose un véritable problème que la communauté des enseignants et celle des chercheurs devraient examiner de concert. Les conclusions hâtives selon lesquelles la prosodie n'est pas si importante et peut, par conséquent, être négligée ; qu'elle n'est finalement pas enseignable parce qu'elle peut difficilement faire l'objet d'un apprentissage - ne sont ni satisfaisantes ni acceptables. C'est pourquoi notre équipe de recherche-action met au centre de son intérêt le travail sur la prise de conscience prosodique, qui peut s'acquérir à travers une implication plus importante du corps et de la voix dans l'apprentissage.

Ce travail est structuré à la fois par un cadre théorique de référence, qui peut devenir un guide pour les enseignants souhaitant intégrer le travail corporel et vocal en classe, et une proposition de pratiques à réaliser avec les enseignants. L'expression « avoir le sens des langues » qui désigne l'aisance que l'on peut avoir dans l'apprentissage d'une langue, a donné le nom à ce cadre de référence : AFEEL. Cet acronyme concentre les principaux ingrédients proposés dans la démarche du groupe : awareness, focus, energy, emotion, liberation. Ils s'articulent autour de deux axes et mettent l'accent sur la compréhension qu'a l'apprenant de son propre corps d'une part: " l'expérience silencieuse » et de sa relation corporelle et vocale avec l'environnement : « le corps engagé ».

TIPA. Travaux interdisciplinaires sur la parole et le langage, 35 | 2019 
La démarche proposée dans ce cadre théorique et pratique s'appuie sur le présupposé que la prise de conscience passe par le corps et les émotions, à la suite des travaux de Damasio (2000) sur « le Sentiment même de soi ", ou de Linklater (2006) sur le rôle de la voix. Ce qui se passe à l'intérieur, chez l'apprenant, devient essentiel. Il s'agit donc d'augmenter les opportunités pour l'apprenant d'être encouragé vers une variation prosodique dans la voix, par une sensibilité accrue à tout ce qui se passe, physiquement et mentalement, dans son corps avant et pendant la parole. D'où l'importance de mobiliser un « contexte émotionnel » Caldwell-Harris (2014), que notre groupe de recherche-action a expérimenté soit d'une manière minimaliste (v. l'analyse des extraits vidéos) soit d'une façon plus prononcée à travers des activités de style théâtral et des travaux d'improvisation (v. la présentation des textes utilisés à cette fin). Par ailleurs, vue l'importance donnée à la co-construction des émotions, ce travail d'improvisation théâtrale offre un cadre idéal pour exploiter des interactions allant dans ce sens.

Les ateliers pratiques proposés aux enseignants-apprenants, autour du corps et de la voix, ne constituent pas une méthode pédagogique à part entière. Les enseignants sont encouragés à identifier eux-mêmes, pendant le cours d'apprentissage de langue, les moments où des activités corporelles et vocales peuvent être insérées. Cependant, le désir d'améliorer la qualité de la communication orale doit être présent dans l'apprentissage de toutes les langues. La description que donne Linklater (2006) de la communication parfaite (bien que rien de parfait n'existe), comme réunissant les émotions, l'intellect, le corps et la voix, devrait servir de guide à l'enseignant en langue pour créer un cours qui englobe tous les aspects de la communication orale. Le rôle de l'improvisation, dans l'approche proposée par notre groupe, offre une excellente occasion de travailler sur l'équilibre de ce quatuor de communication, dans le cadre de l'apprentissage des langues secondes, et cela d'une manière créative, motivante et libératrice pour les enseignants comme pour les apprenants.

\section{INDEX}

Keywords: emotion, oral production, prosody, body, voice

Mots-clés: émotion, production orale, prosodie, corps, voix

\section{AUTHORS}

\section{CHRISTOPHER MITCHELL}

Université Grenoble Alpes, France

christopher.mitchell@univ-grenoble-alpes.fr

\section{REBECCA GUY}

Grenoble INP/ Université Grenoble Alpes, France

Rebecca.Guy@ense3.grenoble-inp.fr

ANDA FOURNEL

Université Grenoble Alpes, France

anda.fournel@univ-grenoble-alpes.fr

\section{AVRIL TREILLE}

Université Grenoble Alpes, France

avril.treille@univ-grenoble-alpes.fr 


\section{MARIEKE DE KONING}

Université Grenoble Alpes, France

marieke.de-koning@univ-grenoble-alpes.fr 